\title{
"One-Pot" Synthesis and Antimalarial Activity of Formamidine Derivatives of 4-Anilinoquinoline
}

\author{
Sandrine Delarue,${ }^{a}$ Sophie Girault, ${ }^{a}$ Fouad Dali Ali, ${ }^{b}$ Louis Maes,${ }^{c}$ Philippe Grellier, ${ }^{b}$ and \\ Christian SergheraerT *,a \\ UMR CNRS 8525, Institut de Biologie et Institut Pasteur de Lille, Faculté de Pharmacie, Université de Lille II, ${ }^{a} 1$ rue du \\ Professeur Calmette, BP 447, 59021 Lille Cedex, France, Laboratoire de Biologie Parasitaire, IFR CNRS 63, Muséum \\ National d'Histoire Naturelle, 61 rue Buffon, 75005 Paris, France, and TIBOTEC, ${ }^{c}$ L11 Général de Wittelaan, B-32800 \\ Mechelen, Belgium. Received December 14, 2000; accepted April 13, 2001
}

\begin{abstract}
Amodiaquine (AQ) is an antimalarial which is effective against chloroquino-resistant strains of Plasmodium falciparum but whose clinical use is severely restricted because of associated hepatotoxicity and agranulocytosis. "One-pot" synthesis of formamidines likely to be transformed into AQ derivatives is reported. Compared with $A Q$, the new compounds were devoid of in vitro cytotoxicity upon human embryonic lung cells and mouse peritoneal macrophages. One showed a potent in vivo activity in mice infected with $P$. berghei. Transformation of this compound by reductive amination led to a new type of $\mathrm{AQ}$ derivatives that displayed an in vitro activity similar to that of $A Q$ but did not lead to toxic quinone-imines.
\end{abstract}

Key words drug design; malaria; Plasmodium falciparum; chloroquine; amodiaquine; formamidine

Today, almost one half of the world's population is exposed to the threat of malaria and the disease was responsible for about 2 million deaths in 1997. ${ }^{1)}$ Quinoline-containing antimalarials, such as chloroquine (CQ, Fig. 1), have long been used in the struggle against malaria. Since its discovery, CQ has proven to be a highly effective, safe, and well-tolerated drug for the treatment and prophylaxis of malaria. But the emergence of CQ-resistant strains has underlined the need for a synthetic alternative to CQ. The spread of resistance ${ }^{2)}$ has prompted the re-examination of alternative antimalarials, such as amodiaquine (AQ, Fig. 1) which was found to be effective against both CQ-sensitive and CQ-resistant strains. ${ }^{3)}$ However, the clinical use of AQ has been severely restricted because of associations with hepatotoxicity and agranulocytosis. ${ }^{4,5)}$ As paracetamol, due to the presence of the $4^{\prime}$-hydroxyl substituent, AQ is known to undergo extensive bioactivation by hepatic cytochrome P-450 enzymes to a chemically reactive quinone-imine (AQQI, Chart 1), followed by nucleophilic addition of glutathione. The formation of these reactive species in vivo and their binding to cellular proteins and lipids could affect cell function either directly or by immune response. ${ }^{6-8)}$ A $4^{\prime}$-dehydroxyfluoro AQ derivative has been reported ${ }^{9)}$ and proved not to give a quinoneimine by simple oxidation. This was reflected in its high oxidation potential and no bioactivation. However, compared with AQ, it was found to be less potent against both CQ-resistant and CQ-sensitive parasites.

With the aim of avoiding bioactivation and toxicity, a se- ries of formamidines likely to be transformed into 4'-dehydroxy AQ derivatives was prepared from the benzylic alcohol 1 (Fig. 2). Formamidines have been used extensively as pharmacological agents, ${ }^{10-12}$ and we have recently described their simple preparation in which bromo-tris-pyrrolidinophosphonium hexafluorophosphate (PyBroP) is used as a convenient activator of the formamide group. ${ }^{13)}$ In the new series, antimalarial activity could be expected from the presence of the amidine side chain capable of interacting with a carboxylate group of heme. The synthesis and antimalarial activity of these compounds (2-6, Fig. 2) are reported as well as those of the AQ analogue (7, Fig. 2) corresponding to the most active among them.

\section{Chemistry}

The synthesis of compound $\mathbf{1}$ and that of the formamidine derivatives 2-7 were carried out as shown in Chart 2. Starting material 1 was obtained by condensation of 4,7-dichloroquinoline with 3,5-diaminobenzyl alcohol according to an
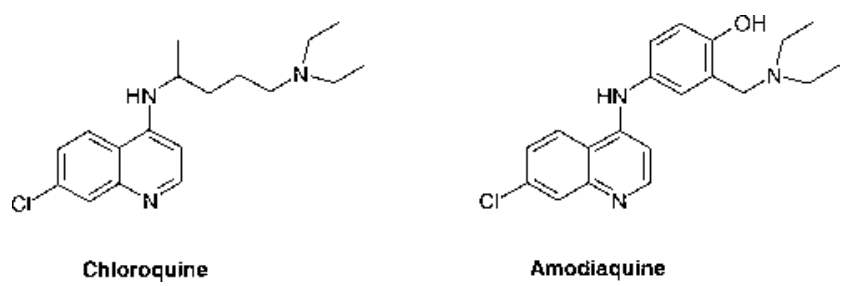

Fig. 1. Structure of Chloroquine and Amodiaquine<smiles>CCNCC1=CC(=Nc2ccnc3cc(Cl)ccc23)C=CC1=O</smiles><smiles></smiles>

Chart 1. Oxidative Pathways of Amodiaquine and Paracetamol 
<smiles>Nc1cc(CO)cc(Nc2ccnc3ccccc23)c1</smiles>

1<smiles>CCNC=Nc1cc(CO)cc(Nc2ccnc3cc(Cl)ccc23)c1</smiles>

2-6

$2-$ NFR' $^{\prime}=$ dimethylamine

$3 \quad-N R^{\prime}=$ piperidine

4 -NRF' = 4-methylpiperidine

5 -NRF' = 4-methylpiperazine

G .NAR' = morpholine<smiles>CCN(CC)Cc1cc(/N=C/N2CCCCC2)cc(Nc2ccnc3cc(Cl)ccc23)c1</smiles>

7

Fig. 2. Structure of Compounds $\mathbf{1}-\mathbf{7}$<smiles>Nc1cc(N)cc(CO)c1</smiles><smiles>Nc1cc(CO)cc(Nc2ccnc3cc(Cl)ccc23)c1</smiles><smiles>N/C=N/c1cc(CO)cc(Nc2ccnc3cc(Cl)ccc23)c1</smiles><smiles>CN(C)/C=N/c1cc(CO)cc(Nc2ccnc3cc(Cl)ccc23)c1</smiles>

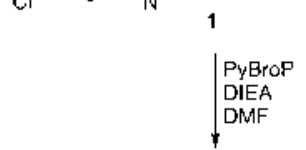<smiles>CCN(CC)Cc1cc(N)cc(Nc2ccnc3cc(Cl)ccc23)c1</smiles>

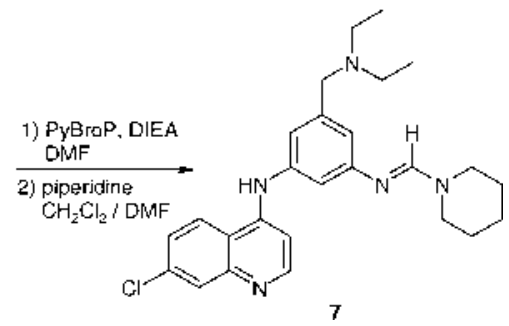

Chart 2. Synthesis of Compounds $\mathbf{1}-\mathbf{7}$

aromatic nucleophilic substitution mechanism. ${ }^{14)}$ Stirring of the reactive medium for $3 \mathrm{~d}$ in a $\mathrm{EtOH} / \mathrm{CHCl}_{3} 55: 5$ mixture, at room temperature, led to the precipitation of compound $\mathbf{1}$, which was collected by filtration. Selective precipitation of compound $\mathbf{1}$ was due to its very poor solubility in EtOH and thus no further purification was necessary. The optimized procedure leads to yields as high as $88 \%$ (Table 1). The absence of formation of the corresponding bisquinoline can be explained both by the precipitation of compound $\mathbf{1}$ and by its capacity for steric hindrance.

Fixation of the amino side chain was carried out in two steps using a "one-pot" procedure. During the first step, compound 2 was obtained by reaction of the PyBroP-activated DMF derivative with compound 1. ${ }^{13)}$ During the second step, the dimethylamino moiety was substituted by various secondary amines HNRR'. Dichloromethane was used as a co-
Table 1. Optimization of the Synthesis of Compound $\mathbf{1}$

\begin{tabular}{ccccc}
\hline \hline Assay & $\begin{array}{c}\text { Ratio } \\
\text { amine/quinoline }\end{array}$ & $\begin{array}{c}\text { Ratio } \\
\mathrm{EtOH} / \mathrm{CHCl}_{3}\end{array}$ & Time (h) & Yield (\%) \\
\hline a & 1 & $70: 10$ & 48 & 56 \\
b & 1 & $55: 5$ & 24 & 50 \\
c & 1 & $55: 5$ & 48 & 85 \\
d & 1 & $55: 5$ & 72 & 88
\end{tabular}

solvent to permit reduction at reflux temperature and thus avoid the degradation of the formamidine into formamide. Amine conversion rates were quantitative, but strong interactions between the final products and silica phase during chromatography purification led to moderate yields $(27-43 \%)$.

Synthesis of compound 7 from compound $\mathbf{1}$ was carried 
Table 2. In Vitro Antimalarial Activity against P. falciparum FcB1R Strain and in Vitro Cytotoxicity upon MRC-5 Cells and Mouse Peritoneal Macrophages of Compounds $1-7$

\begin{tabular}{|c|c|c|c|c|c|c|}
\hline \multirow{2}{*}{ Compound } & \multirow{2}{*}{$\begin{array}{c}\mathrm{IC}_{50}(\mathrm{nM}) \\
\text { against FcB1R }\end{array}$} & \multicolumn{4}{|c|}{ Cytotoxicity (\%) upon MRC-5 at $(\mu \mathrm{M})$} & \multirow{2}{*}{$\begin{array}{c}\text { Cytotoxicity upon MPM } \\
\text { No toxicity at }(\mu \mathrm{M})\end{array}$} \\
\hline & & 25 & 12.5 & 6.3 & 3.1 & \\
\hline $\mathrm{CQ}$ & 142 & 0 & 0 & 0 & 0 & 12.5 \\
\hline $\mathrm{AQ}$ & 20 & 91 & 0 & 0 & 0 & 3.1 \\
\hline 1 & 300 & 20 & 0 & 0 & 0 & 12.5 \\
\hline 2 & 520 & 0 & 0 & 0 & 0 & 12.5 \\
\hline 3 & 170 & 0 & 0 & 0 & 0 & 12.5 \\
\hline 4 & 190 & 0 & 0 & 0 & 0 & 12.5 \\
\hline 5 & 600 & 0 & 0 & 0 & 0 & 12.5 \\
\hline 6 & 550 & 0 & 0 & 0 & 0 & 12.5 \\
\hline 7 & 20 & 90 & 5 & 0 & 0 & 12.5 \\
\hline
\end{tabular}

out in three steps. The benzylic alcohol group of compound $\mathbf{1}$ was first converted into an aldehyde by oxidation with $\mathrm{MnO}_{2}$, followed by reductive amination with diethylamine using sodium triacetoxyborohydride as reducing agent (Chart 2). ${ }^{15}$ ) A low yield was observed because of a side reaction during the oxidation step, since the amine moiety of the molecule can react with the aldehyde group of another molecule leading to a polymerization product. The previous protection of the amine moiety by a Fmoc or by a Boc group was found to be unsuccessful. In the final step, the procedure used for compounds 3-6 was applied to obtain the desired compound 7 in $45 \%$ yield.

\section{Biological Results and Discussion}

All compounds were tested for their antimalarial potency against a CQ-resistant FcB1R strain $\left(\mathrm{IC}_{50} \mathrm{CQ}=142 \mathrm{nM}\right)$ and for their cytotoxicity upon human MRC-5 cells (human diploid embryonic lung cell line) and mouse primary peritoneal macrophages (MPM) (Table 2).

Formamidines $\mathbf{2}-\mathbf{6}$ were found to be less active than AQ in vitro against the $\mathrm{CQ}$-resistant $\mathrm{FcB} 1 \mathrm{R}$ strain but were non cytotoxic at a concentration of $25 \mu \mathrm{M}$ upon MRC-5 cells as well as upon MPM. Two compounds, 3 and 4, displayed an in vitro antimalarial effect against the FcB1R strain in the same range as that of CQ while the others were less active. Therefore the presence in the side chain of a cyclic tertiary amine without an additional hetero atom appears favourable for antimalarial activity. The most active, compound $\mathbf{3}$, was then tested in vitro against two other strains of $P$. falciparum, F32a and $\mathrm{PFB}$, which are respectively more CQ-sensitive $\left(\mathrm{IC}_{50}\right.$ $\mathrm{CQ}=25 \mathrm{nM})$ and more CQ-resistant $\left(\mathrm{IC}_{50} \mathrm{CQ}=340 \mathrm{~nm}\right)$ than the FcB1R strain. $\mathrm{IC}_{50}$ values of compound 3 were, respectively, 80 and $355 \mathrm{nM}$, thus revealing a correlation with CQ values and potentially a mode of action similar to both $\mathrm{CQ}$ and $\mathrm{AQ}$, i.e. by inhibiting heme polymerization. ${ }^{16)}$ Compound 3 was also tested at $40 \mathrm{mg} / \mathrm{kg}$ in mice infected with Plasmodium berghei. While the control mice died $7 \mathrm{~d}$ following infection, animals receiving compound $\mathbf{3}$ displayed a $60 \%$ reduction in parasitemia at $7 \mathrm{~d}$ and mean survival time of about $19 \mathrm{~d}$.

AQ derivative $\mathbf{7}$, corresponding to the formamidine $\mathbf{3}$, was synthesized and displayed an activity similar to that of AQ against the CQ-resistant FcB1R strain while its cytotoxicity was slightly inferior to that of AQ. Therefore it proved to be more active than 4'-dehydroxyfluoro AQ which displayed a 2-fold increase in $\mathrm{IC}_{50}$ values when compared with $\mathrm{AQ}$ against both CQ-sensitive and -resistant strains. ${ }^{9)}$ In the $4^{\prime}$ dehydroxyfluoro AQ, the lack of the hydrogen bond, which is present in AQ between the phenol group and the diethylamino moiety, was responsible for the decreased activity. In compound 7, this phenomenon is balanced by an additional amino moiety. The increase in activity observed can be explained by the presence of a bis-cationic site, likely to interact simultaneously with the two carboxylate groups of heme. Moreover, its synthesis is simple, when compared with the five steps, including use of bromine, irradiation, and catalytical hydrogenation, required to prepare 4 '-dehydroxyfluoro AQ.

In conclusion, a series of formamidines without the hydroxyl group of AQ, eliciting hepatotoxicity and aganulocytosis by bioactivation, was synthesized using a "one-pot" method from an aminoalcohol, easily obtained by precipitation. The new compounds are non cytotoxic upon a human embryonic lung cell line and upon MPM. The most active among them has an in vitro antimalarial activity in the same range as $\mathrm{CQ}$ against three strains varying in their resistance to CQ, while also demonstrating an activity against $P$. berghei in mice. These formamidines are intermediates for the facile synthesis of new AQ derivatives, have activity similar to that of AQ with less cytotoxicity, and do not lead to toxic quinone-imine formation.

\section{Experimental}

Chemistry All reactions were monitored using thin-layer chromatography carried out on $0.2 \mathrm{~mm}$ E. Merck silica gel plates (60F-254) using UV light as visualizing agent. ${ }^{1} \mathrm{H}-\mathrm{NMR}$ spectra were obtained using a Brücker $300 \mathrm{MHz}$ spectrometer. Mass spectra were recorded on a time-of-flight plasma desorption mass spectrometer (TOF-PDMS) using a Californium source. Chromatography was carried out using silica gel 60 (230-400 mesh ASTM) from Macherey-Nagel. Thick-layer chromatography (TLC) was performed using silica gel from Merck and the compounds were extracted from silica gel using the following solvent system: $\mathrm{CH}_{2} \mathrm{Cl}_{2} / \mathrm{MeOH} 80: 20$. The melting point (mp) of the chlorhydrate form for compounds $\mathbf{1}-\mathbf{6}$ and of the basic form for compound 7 were determined on a Büchi 535 capillary mp apparatus and were uncorrected. The purity of final compounds was checked by high pressure liquid chromatography $\left(\mathrm{P}_{\mathrm{HPLC}}\right)$ with a $\mathrm{C} 18$ Vydac column. Analytical HPLC was performed on a Shimadzu system equipped with a UV detector set at $254 \mathrm{~nm}$. Compounds were dissolved in $\mathrm{MeOH}$ and injected through a $50 \mu 1$ loop. The following eluent systems were used: $\mathrm{A}\left(\mathrm{H}_{2} \mathrm{O} / \mathrm{TFA}\right.$, $100: 0.05)$ and $\mathrm{B}\left(\mathrm{CH}_{3} \mathrm{CN} / \mathrm{H}_{2} \mathrm{O} / \mathrm{TFA}, 80: 20: 0.05\right)$. HPLC retention times (HPLC $t_{\mathrm{R}}$ ) were obtained at flow rates of $1 \mathrm{ml} / \mathrm{min}$ using a gradient run from $100 \%$ eluent A for $5 \mathrm{~min}$ and then to $100 \%$ eluent B over the next $25 \mathrm{~min}$. CQ and AQ were obtained from Aldrich and Sigma, respectively. 4,7Dichloroquinoline and 3,5-diaminobenzyl alcohol dihydrochloride were obtained from Aldrich.

Procedure for Chlorhydrate Salts Trimethylchlorosilane (1 eq) was 
added to a solution of formamidine (1 eq) in $\mathrm{MeOH}$. After stirring the mixture for $15 \mathrm{~min}$ at room temperature, the solvent was evaporated to yield the desired chlorhydrate.

\{3-Amino-5-[(7-chloro-4-quinolyl)amino]phenyl\}methanol (1) To a solution of 4,7-dichloroquinoline $(1.88 \mathrm{~g}, 9.5 \mathrm{mmol}, 1 \mathrm{eq})$, and $N$-methylmorpholine $(1.3 \mathrm{ml}, 11.8 \mathrm{mmol}, 1.2 \mathrm{eq})$, in EtOH $50 \mathrm{ml}$ was added a solution of 3,5-diaminobenzyl alcohol dihydrochloride ( $2 \mathrm{~g}, 9.5 \mathrm{mmol}, 1 \mathrm{eq})$, and $N$ methylmorpholine $(1.7 \mathrm{ml}, 15.5 \mathrm{mmol}, 1.6 \mathrm{eq})$, in a $\mathrm{EtOH} / \mathrm{CHCl}_{3} 50: 50$ mixture $10 \mathrm{ml}$, at $0{ }^{\circ} \mathrm{C}$. After stirring for $72 \mathrm{~h}$ at room temperature, the mixture was filtered and the residual solid washed with ice cold $\mathrm{EtOH}$ and dried to yield compound 1 as a yellow solid. Yield: $88 \%(2.5 \mathrm{~g}) . \mathrm{mp}: 206^{\circ} \mathrm{C} . R f$ : $0.13\left(\mathrm{CH}_{2} \mathrm{Cl}_{2} / \mathrm{MeOH}, 9: 1\right) .{ }^{1} \mathrm{H}-\mathrm{NMR}$ (DMSO-d $) \delta: 2.70(1 \mathrm{H}, \mathrm{s}, \mathrm{OH}), 3.60$ $\left(2 \mathrm{H}\right.$, br s, $\left.\mathrm{NH}_{2}\right), 4.47\left(2 \mathrm{H}, \mathrm{s}, \mathrm{CH}_{2}\right), 6.82(1 \mathrm{H}, \mathrm{d}, J=7.0 \mathrm{~Hz}, \mathrm{H}$ quinoline), $6.85(1 \mathrm{H}, \mathrm{s}, \mathrm{Ar}-\mathrm{H}), 6.92(2 \mathrm{H}, \mathrm{s}, \mathrm{Ar}-\mathrm{H}), 7.84(1 \mathrm{H}, \mathrm{dd}, J=9.1,2.1 \mathrm{~Hz}, \mathrm{H}$ quinoline), $8.10(1 \mathrm{H}, \mathrm{d}, J=2.0 \mathrm{~Hz}, \mathrm{H}$ quinoline $), 8.52(1 \mathrm{H}, \mathrm{d}, J=7.0 \mathrm{~Hz}, \mathrm{H}$ quinoline), $8.78(1 \mathrm{H}, \mathrm{d}, J=9.2 \mathrm{~Hz}, \mathrm{H}$ quinoline $), 11.06(1 \mathrm{H}, \mathrm{s}, \mathrm{NH})$. TOFPDMS $m / z$ : $299.4\left(\mathrm{M}^{+}\right)$. HPLC: $\mathrm{P}_{\mathrm{HPLC}} 98 \%, t_{\mathrm{R}} 11.85 \mathrm{~min}$.

$\boldsymbol{N}^{\prime}$-\{3-[(7-Chloro-4-quinolyl)amino]-5-[hydroxymethyl]phenyl\}- $N, \boldsymbol{N}$ dimethyliminoformamide (2) To a solution of compound $\mathbf{1}$ (150 mg, 0.5 mmol, 1 eq), in DMF $10 \mathrm{ml}$ were added DIEA ( $88 \mu \mathrm{l}, 1 \mathrm{mmol}, 2 \mathrm{eq})$, and PyBroP $(235 \mathrm{mg}, 0.5 \mathrm{mmol}, 1 \mathrm{eq})$. After stirring the mixture for $7 \mathrm{~h}$ at room temperature, the solvent was evaporated, the solid residue washed with $1 \mathrm{M}$ $\mathrm{NaHCO}_{3} 15 \mathrm{ml}$ and purified by TLC $\left(\mathrm{CH}_{2} \mathrm{Cl}_{2} / \mathrm{MeOH}, 60: 40\right)$, to yield compound 2 as a yellow solid. Yield: $42 \%(50 \mathrm{mg})$. mp: $166^{\circ} \mathrm{C}$. Rf: 0.37 $\left(\mathrm{CH}_{2} \mathrm{Cl}_{2} / \mathrm{MeOH}, 6: 4\right) .{ }^{1} \mathrm{H}-\mathrm{NMR}\left(\mathrm{DMSO}-d_{6}\right) \delta: 2.87\left(3 \mathrm{H}\right.$, br s, $\left.\mathrm{CH}_{3}\right), 2.94$ $\left(3 \mathrm{H}\right.$, br s, $\left.\mathrm{CH}_{3}\right), 4.42\left(2 \mathrm{H}, \mathrm{s}, \mathrm{CH}_{2}-\mathrm{Ph}\right), 5.11(1 \mathrm{H}$, br s, OH), $6.63(1 \mathrm{H}, \mathrm{s}, \mathrm{Ar}-$ $\mathrm{H}), 6.71(1 \mathrm{H}, \mathrm{s}, \mathrm{Ar}-\mathrm{H}), 6.86(1 \mathrm{H}, \mathrm{s}, \mathrm{Ar}-\mathrm{H}), 6.89(1 \mathrm{H}, \mathrm{d}, J=5.4 \mathrm{~Hz}, \mathrm{H}$ quinoline), $7.50(1 \mathrm{H}, \mathrm{dd}, J=9.0,2.1 \mathrm{~Hz}, \mathrm{H}$ quinoline $), 7.71(1 \mathrm{H}, \mathrm{s}, \mathrm{N}=\mathrm{C} \underline{\mathrm{H}}-$ $\left.\mathrm{NRR}^{\prime}\right), 7.83(1 \mathrm{H}, \mathrm{d}, J=2.2 \mathrm{~Hz}, \mathrm{H}$ quinoline $), 8.38(1 \mathrm{H}, \mathrm{d}, J=8.8 \mathrm{~Hz}, \mathrm{H}$ quinoline), $8.41(1 \mathrm{H}, \mathrm{d}, J=5.2 \mathrm{~Hz}, \mathrm{H}$ quinoline), $8.94(1 \mathrm{H}, \mathrm{s}, \mathrm{NH})$. TOFPDMS $m / z$ : $354.8\left(\mathrm{M}^{+}\right)$. HPLC: $\mathrm{P}_{\mathrm{HPLC}} 94 \%, t_{\mathrm{R}} 11.00 \mathrm{~min}$.

General Procedure for Synthesis of Compounds 3-6 To a solution of compound 1 (150 mg, $0.5 \mathrm{mmol}, 1 \mathrm{eq})$, in DMF $10 \mathrm{ml}$ were added DIEA ( $88 \mu \mathrm{l}, 1 \mathrm{mmol}, 2 \mathrm{eq})$, and PyBroP (235 mg, $0.5 \mathrm{mmol}, 1 \mathrm{eq})$. After stirring the mixture for $12 \mathrm{~h}$ at room temperature, the appropriate amine $(4 \mathrm{mmol}, 8$ eq) was added. Following reflux of the mixture for $5 \mathrm{~h}$, the solvent was evaporated, the solid residue washed with $1 \mathrm{M} \mathrm{NaHCO} 315 \mathrm{ml}$ and purified by TLC $\left(\mathrm{CH}_{2} \mathrm{Cl}_{2} / \mathrm{MeOH}, 70: 30\right)$, to yield the desired compound.

\{3-[(7-Chloro-4-quinolyl)amino]-5-[(piperidinomethylidene)amino]phenyl\}methanol (3) Yellow solid. Yield: 40\% (80 mg). mp: $231^{\circ} \mathrm{C}$. $R f$ : $0.66\left(\mathrm{CH}_{2} \mathrm{Cl}_{2} / \mathrm{MeOH}, 7: 3\right)$. ${ }^{1} \mathrm{H}-\mathrm{NMR}$ (DMSO-d $)_{6} \delta: 1.55-1.57(2 \mathrm{H}, \mathrm{m}$, $\mathrm{CH}_{2}$ piperidine), $1.66-1.70\left(4 \mathrm{H}, \mathrm{m}, \mathrm{CH}_{2}\right.$ piperidine $), 2.93-2.99(4 \mathrm{H}, \mathrm{m}$, $\mathrm{CH}_{2}$ piperidine), $4.42\left(2 \mathrm{H}, \mathrm{s}, \mathrm{CH}_{2}-\mathrm{Ph}\right), 5.10(1 \mathrm{H}$, br s, OH), $6.63(1 \mathrm{H}, \mathrm{s}, \mathrm{Ar}-$ $\mathrm{H}), 6.70(1 \mathrm{H}, \mathrm{s}, \mathrm{Ar}-\mathrm{H}), 6.86(1 \mathrm{H}, \mathrm{s}, \mathrm{Ar}-\mathrm{H}), 6.89(1 \mathrm{H}, \mathrm{d}, J=5.4 \mathrm{~Hz}, \mathrm{H}$ quinoline), $7.49(1 \mathrm{H}, \mathrm{dd}, J=9.0,2.3 \mathrm{~Hz}, \mathrm{H}$ quinoline $), 7.69(1 \mathrm{H}, \mathrm{s}, \mathrm{N}=\mathrm{C} \underline{\mathrm{H}}-$ $\left.\mathrm{NRR}^{\prime}\right), 7.83(1 \mathrm{H}, \mathrm{d}, J=2.2 \mathrm{~Hz}, \mathrm{H}$ quinoline $), 8.38(1 \mathrm{H}, \mathrm{d}, J=9.1 \mathrm{~Hz}, \mathrm{H}$ quinoline), $8.40(1 \mathrm{H}, \mathrm{d}, J=5.3 \mathrm{~Hz}, \mathrm{H}$ quinoline), $8.95(1 \mathrm{H}, \mathrm{s}, \mathrm{NH})$. TOFPDMS $m / z$ : $394.8\left(\mathrm{M}^{+}\right)$. HPLC: $\mathrm{P}_{\mathrm{HPLC}} 95 \%, t_{\mathrm{R}} 12.12 \mathrm{~min}$.

\{3-[(7-Chloro-4-quinolyl)amino]-5-[(\{4-methylpiperidino\} methylidene)amino]phenyl\}methanol (4) Yellow solid. Yield: $37 \%(75 \mathrm{mg}) . \mathrm{mp}$ : $188^{\circ} \mathrm{C} . R f: 0.70\left(\mathrm{CH}_{2} \mathrm{Cl}_{2} / \mathrm{MeOH}, 8: 2\right) .{ }^{1} \mathrm{H}-\mathrm{NMR}\left(\mathrm{DMSO}-d_{6}\right) \delta: 0.99(3 \mathrm{H}, \mathrm{d}$, $\left.J=6.4 \mathrm{~Hz}, \mathrm{CH}_{3}\right), 1.12\left(2 \mathrm{H}, \mathrm{m}, \mathrm{CH}_{2}\right.$ piperidine), $1.29(1 \mathrm{H}, \mathrm{s}, \mathrm{CH}$ piperidine), 1.65-1.80 (4H, m, $\mathrm{CH}_{2}$ piperidine), $3.06\left(2 \mathrm{H}, \mathrm{m}, \mathrm{CH}_{2}\right.$ piperidine), 4.52 $\left(2 \mathrm{H}, \mathrm{d}, J=5.8 \mathrm{~Hz}, \mathrm{CH}_{2}-\mathrm{Ph}\right), 5.19(1 \mathrm{H}, \mathrm{t}, J=5.8 \mathrm{~Hz}, \mathrm{OH}), 6.73(1 \mathrm{H}, \mathrm{s}, \mathrm{Ar}-\mathrm{H})$, $6.80(1 \mathrm{H}, \mathrm{s}, \mathrm{Ar}-\mathrm{H}), 6.97(1 \mathrm{H}, \mathrm{s}, \mathrm{Ar}-\mathrm{H}), 6.99(1 \mathrm{H}, \mathrm{d}, J=5.4 \mathrm{~Hz}, \mathrm{H}$ quinoline), 7.60 (1H, dd, $J=9.0,2.2 \mathrm{~Hz}, \mathrm{H}$ quinoline), 7.80 (1H, s, N=CH-NRR'), 7.93 (1H, d, $J=2.2 \mathrm{~Hz}, \mathrm{H}$ quinoline), $8.48(1 \mathrm{H}, \mathrm{d}, J=9.1 \mathrm{~Hz}, \mathrm{H}$ quinoline), 8.51 (1H, d, $J=5.3 \mathrm{~Hz}, \mathrm{H}$ quinoline), $9.04(1 \mathrm{H}, \mathrm{s}, \mathrm{NH})$. TOF-PDMS $m / z: 408.4$ $\left(\mathrm{M}^{+}\right)$. HPLC: $\mathrm{P}_{\mathrm{HPLC}} 95 \%, t_{\mathrm{R}} 13.19 \mathrm{~min}$.

\{3-[(7-Chloro-4-quinolyl)amino]-5-[(\{4-methylpiperazino\}methylidene)aminolphenyl methanol (5) Yellow solid. Yield: $27 \%(55 \mathrm{mg}) . \mathrm{mp}$ : $195^{\circ} \mathrm{C} . R f: 0.28\left(\mathrm{CH}_{2} \mathrm{Cl}_{2} / \mathrm{MeOH}, 7: 3\right) .{ }^{1} \mathrm{H}-\mathrm{NMR}$ (DMSO-d $) \delta: 2.16(3 \mathrm{H}, \mathrm{s}$, $\left.\mathrm{CH}_{3}\right), 2.27\left(4 \mathrm{H}, \mathrm{t}, J=5.1 \mathrm{~Hz}, \mathrm{CH}_{2}\right.$ piperazine $), 3.40-3.50\left(4 \mathrm{H}, \mathrm{m}, \mathrm{CH}_{2}\right.$ piperazine), $4.42\left(2 \mathrm{H}, \mathrm{s}, \mathrm{CH}_{2}-\mathrm{Ph}\right), 5.10(1 \mathrm{H}$, br s, OH), $6.64(1 \mathrm{H}, \mathrm{s}, \mathrm{Ar}-\mathrm{H})$, $6.72(1 \mathrm{H}, \mathrm{s}, \mathrm{Ar}-\mathrm{H}), 6.88(1 \mathrm{H}, \mathrm{s}, \mathrm{Ar}-\mathrm{H}), 6.89(1 \mathrm{H}, \mathrm{d}, J=5.4 \mathrm{~Hz}, \mathrm{H}$ quinoline), 7.50 (1H, dd, $J=9.0,2.2 \mathrm{~Hz}, \mathrm{H}$ quinoline), 7.73 (1H, s, N=Cㅍ-NRR'), 7.83 (1H, d, $J=2.2 \mathrm{~Hz}, \mathrm{H}$ quinoline $), 8.38(1 \mathrm{H}, \mathrm{d}, J=8.9 \mathrm{~Hz}, \mathrm{H}$ quinoline $), 8.41$ (1H, d, $J=5.3 \mathrm{~Hz}, \mathrm{H}$ quinoline), 8.95 (1H, s, NH). TOF-PDMS $m / z: 409.9$ $\left(\mathrm{M}^{+}\right)$. HPLC: $\mathrm{P}_{\mathrm{HPLC}} 95 \%, t_{\mathrm{R}} 12.09 \mathrm{~min}$.

\{3-[(7-Chloro-4-quinolyl)amino]-5-[(morpholinomethylidene)amino]phenyl\}methanol (6) Yellow solid. Yield: $43 \%(85 \mathrm{mg}) . \mathrm{mp}>250{ }^{\circ} \mathrm{C} . R f$ : $0.83\left(\mathrm{CH}_{2} \mathrm{Cl}_{2} / \mathrm{MeOH}, 7: 3\right) .{ }^{1} \mathrm{H}-\mathrm{NMR}$ (DMSO-d $) \delta: 3.37-3.49(4 \mathrm{H}, \mathrm{m}$, $\mathrm{CH}_{2}$ morpholine), 3.55-3.58 (4H, m, $\mathrm{CH}_{2}$ morpholine), $4.43(2 \mathrm{H}, \mathrm{d}, J=5.5$ $\left.\mathrm{Hz}, \underline{\mathrm{CH}}_{2}-\mathrm{Ph}\right), 5.13(1 \mathrm{H}, \mathrm{t}, J=5.5 \mathrm{~Hz}, \mathrm{OH}), 6.65(1 \mathrm{H}, \mathrm{s}, \mathrm{Ar}-\mathrm{H}), 6.73(1 \mathrm{H}, \mathrm{s}$,
Ar-H), $6.88(1 \mathrm{H}, \mathrm{s}, \mathrm{Ar}-\mathrm{H}), 6.94(1 \mathrm{H}, \mathrm{d}, J=5.3 \mathrm{~Hz}, \mathrm{H}$ quinoline $), 7.50(1 \mathrm{H}$, dd, $J=9.0,2.2 \mathrm{~Hz}, \mathrm{H}$ quinoline $), 7.76\left(1 \mathrm{H}, \mathrm{s}, \mathrm{N}=\mathrm{C} \underline{\mathrm{H}}-\mathrm{NRR}^{\prime}\right), 7.85(1 \mathrm{H}, \mathrm{d}$, $J=2.2 \mathrm{~Hz}, \mathrm{H}$ quinoline $), 8.38(1 \mathrm{H}, \mathrm{d}, J=9.3 \mathrm{~Hz}, \mathrm{H}$ quinoline $), 8.41(1 \mathrm{H}, \mathrm{d}$, $J=5.3 \mathrm{~Hz}, \mathrm{H}$ quinoline), $8.96(1 \mathrm{H}, \mathrm{s}, \mathrm{NH})$. TOF-PDMS $m / z: 396.7\left(\mathrm{M}^{+}\right)$. HPLC: $P_{\text {HPLC }} 99 \%, t_{\mathrm{R}} 11.09 \mathrm{~min}$.

$N$-\{3-[(7-Chloro-4-quinolyl)amino]-5-I(piperidinomethylidene)amino]phenyl $\}$ methyl- $N, N$-diethyl amine (7) To a solution of compound $1(600 \mathrm{mg}, 2 \mathrm{mmol}, 1 \mathrm{eq})$, in a $\mathrm{CH}_{2} \mathrm{Cl}_{2} / \mathrm{DMF} 60: 1$ mixture $35 \mathrm{ml}$ were added DIEA ( $350 \mu 1,2 \mathrm{mmol}, 2 \mathrm{eq})$, and $\mathrm{MnO}_{2}(2.6 \mathrm{~g}, 30 \mathrm{mmol}, 15 \mathrm{eq})$. After stirring the mixture for $18 \mathrm{~h}$ at room temperature, the mixture was filtrated on celite and the solid residue washed with $\mathrm{CH}_{2} \mathrm{Cl}_{2} 30 \mathrm{ml}$. To the filtrate was then added diethylamine $(1 \mathrm{ml}, 10 \mathrm{mmol}, 5 \mathrm{eq})$, and, after stirring at room temperature for $1 \mathrm{~h}, \mathrm{NaHB}(\mathrm{OAc})_{3}(1.2 \mathrm{~g}, 6 \mathrm{mmol}, 3 \mathrm{eq})$ was added. Following further stirring at room temperature for $18 \mathrm{~h}$, aqueous $\mathrm{NaHCO}_{3} 1 \mathrm{~m}$ was introduced and the mixture was left to stir for $15 \mathrm{~min}$. The organic layer was then separated, and the aqueous layer washed with $\mathrm{CH}_{2} \mathrm{Cl}_{2}$. The organic layers were combined, washed with brine, separated and dried over $\mathrm{MgSO}_{4}$. The solvent was evaporated and the residue purified by TLC $\left(\mathrm{CH}_{2} \mathrm{Cl}_{2} /\right.$ $\mathrm{MeOH}, 80: 20)$ to yield the desired intermediate in $30 \%$ yield $(210 \mathrm{mg})$. To a solution of this intermediate $(130 \mathrm{mg}, 0.37 \mathrm{mmol}, 1 \mathrm{eq})$ in DMF $10 \mathrm{ml}$ were added DIEA ( $65 \mu 1,0.73 \mathrm{mmol}, 2 \mathrm{eq}$ ), and PyBroP (180 mg, $0.39 \mathrm{mmol}, 1.1$ eq). After stirring the mixture for $12 \mathrm{~h}$ at room temperature, piperidine was added $(145 \mu \mathrm{l}, 1.47 \mathrm{mmol}, 4 \mathrm{eq})$. Following reflux of the mixture for $5 \mathrm{~h}$, the solvent was evaporated, the solid residue washed with $1 \mathrm{M} \mathrm{NaHCO} 315 \mathrm{ml}$ and purified by TLC $\left(\mathrm{CH}_{2} \mathrm{Cl}_{2} / \mathrm{MeOH}, 80: 20\right)$, to yield compound 7 as a yellow solid. Yield: $45 \%(75 \mathrm{mg})$. mp: $79^{\circ} \mathrm{C}$. Rf: $0.30\left(\mathrm{CH}_{2} \mathrm{Cl}_{2} / \mathrm{MeOH}, 7: 3\right)$. ${ }^{1} \mathrm{H}-\mathrm{NMR}$ (DMSO- $\left.d_{6}\right) \delta: 1.00\left(6 \mathrm{H}, \mathrm{t}, J=4.6 \mathrm{~Hz}, \mathrm{CH}_{2} \mathrm{CH}_{3}\right), 1.52-1.54(2 \mathrm{H}$, $\mathrm{m}, \mathrm{CH}_{2}$ piperidine $), 1.57-1.66\left(4 \mathrm{H}, \mathrm{m}, \mathrm{CH}_{2}\right.$ piperidine $), 2.90-3.03(8 \mathrm{H}$, $\mathrm{m}, \mathrm{CH}_{2}$ piperidine and $\left.\underline{\mathrm{CH}}_{2} \mathrm{CH}_{3}\right), 3.55\left(2 \mathrm{H}, \mathrm{s}, \mathrm{CH}_{2}-\mathrm{Ph}\right), 6.64(1 \mathrm{H}, \mathrm{s}, \mathrm{Ar}-\mathrm{H})$, $6.72(1 \mathrm{H}, \mathrm{s}, \mathrm{Ar}-\mathrm{H}), 6.95(1 \mathrm{H}, \mathrm{d}, J=5.4 \mathrm{~Hz}, \mathrm{H}$ quinoline $), 7.00(1 \mathrm{H}, \mathrm{s}, \mathrm{Ar}-\mathrm{H})$, $7.48(1 \mathrm{H}, \mathrm{dd}, J=9.0,2.3 \mathrm{~Hz}, \mathrm{H}$ quinoline $), 7.85(1 \mathrm{H}, \mathrm{d}, J=2.2 \mathrm{~Hz}, \mathrm{H}$ quinoline), $8.28\left(1 \mathrm{H}, \mathrm{s}, \mathrm{N}=\mathrm{C} \underline{\mathrm{H}}-\mathrm{NRR}^{\prime}\right), 8.42(1 \mathrm{H}, \mathrm{d}, J=9.1 \mathrm{~Hz}, \mathrm{H}$ quinoline $), 8.46$ $(1 \mathrm{H}, \mathrm{d}, J=5.3 \mathrm{~Hz}, \mathrm{H}$ quinoline), $9.02(1 \mathrm{H}, \mathrm{s}, \mathrm{NH})$. TOF-PDMS $m / z: 450.6$ $\left(\mathrm{M}^{+}\right)$. HPLC: $\mathrm{P}_{\mathrm{HPLC}} 100 \%, t_{\mathrm{R}} 12.68 \mathrm{~min}$.

Biological Evaluation Compounds $\mathbf{1}-\mathbf{6}$ were evaluated in their chlorhydrate form and compound 7 in its basic form.

In Vitro P. falciparum Culture and Drug Assays P. falciparum strains were maintained continuously in culture on human erythrocytes as described by Trager and Jensen. ${ }^{17)}$ In vitro antiplasmodial activity was determined using a modification of the semi-automated microdilution technique of Desjardins et al. ${ }^{18)}$ P. falciparum CQ-sensitive (F32a/Tanzania) and CQ-resistant (FcB1R/Colombia, PFB/Brazil) strains were used in sensitivity testing. FcB1R, F32a, and PFB strains were obtained by limit dilution. Stock solutions of CQ diphosphate and test compounds were prepared in sterile, distilled water and DMSO, respectively. Drug solutions were serially diluted with culture medium and added to asynchronous parasite cultures $(0.5 \%$ parasitemia and $1 \%$ final hematocrit) in 96 -well plates for $24 \mathrm{~h}$, at $37^{\circ} \mathrm{C}$, prior to the addition of $\left[{ }^{3} \mathrm{H}\right]$ hypoxanthine $0.5 \mu \mathrm{Ci}$ ( 1 to $5 \mathrm{Ci} / \mathrm{mmol}$; Amersham, Les Ulis, France) per well for $24 \mathrm{~h}$. The growth inhibition for each drug concentration was determined by comparison of the radioactivity incorporated in the treated culture with that in the control culture (without drug) maintained on the same plate. The concentration causing $50 \%$ inhibition $\left(\mathrm{IC}_{50}\right)$ was obtained from the drug concentration-response curve and the results were expressed as the mean from two independent experiments. The DMSO concentration never exceeded $0.1 \%$ and did not inhibit parasite growth.

Cytotoxicity Evaluation upon Human MRC-5 Cells and MPM A human diploid embryonic lung cell line (MRC-5, Bio-Whittaker 72211D) and MPM were used to assess cytotoxicity in host cells. The MPM were collected from the peritoneal cavity $48 \mathrm{~h}$ after stimulation with potato starch and seeded in 96-well microplates at 30000 cells per well. MRC-5 cells were seeded at 5000 cells per well. After $24 \mathrm{~h}$, the cells were washed and 2-fold dilutions of the drug were added in standard culture medium (RPMI $+5 \%$ fetal calf serum) $200 \mu \mathrm{l}$. The final DMSO concentration in the culture remained below $0.5 \%$. The cultures were incubated with four concentrations of compounds $(25,12.5,6.3$ and $3.1 \mu \mathrm{M})$ at $37{ }^{\circ} \mathrm{C}$ in $5 \% \mathrm{CO}_{2}-95 \%$ air for 7 d. Untreated cultures were included as controls. For MRC- 5 cells, the cytotoxicity was determined using the colorimetric 3-(4,5-dimethylthiazol-2-yl)2,5-diphenyl-tetrazolium bromide (thiazolyl blue) assay. ${ }^{19)}$ The concentration causing $50 \%$ reduction of viable cells $\left(\mathrm{CC}_{50}\right)$ was obtained from the drug concentration-response curve. For macrophages, scoring was performed microscopically.

In Vivo Drug Assays in P. berghei-Infected Mice The in vivo antimalarial activities were determined in mice infected with $P$. berghei (ANKA 65 strain). Four-week-old female Swiss mice (CD-1, 20-25g) were in- 
traperitoneally infected with about $10^{7}$ parasitized erythrocytes, collected from the blood of an acutely infected donor animal. At the same time, the animals ( 3 animals per group) were orally administrated the test compound at a dose of $40 \mathrm{mg} / \mathrm{kg}$ (drug formulation in $100 \%$ DMSO). The administration continued on the 4 subsequent days by the intraperitoneal route. Untreated control animals generally die between $7-10 \mathrm{~d}$ following infection. Drug activity was evaluated as the prolongation of the mean survival time observed in untreated controls and/or by the reduction in parasitemia at $7 \mathrm{~d}$ after infection. The suppression of parasitemia was calculated by the formula: (average \% parasitemia in controls - average \% parasitemia in treated mice)/average \% parasitemia in controls. Three infected, DMSO-dosed mice were used as controls.

Acknowledgments We express our thanks to Gérard Montagne for NMR experiments and Dr. Steve Brooks for proof reading. This work was supported by CNRS (EP CNRS 1790, UMR CNRS 8525) and Université de Lille II. S. D. is a recipient of fellowships from the Région Nord-Pas de Calais.

\section{References}

1) World Health Organisation, "The World Health Report, Conquering, Suffering, Enriching Humanity," World Health Organisation Publishers, Geneva, 1997.

2) World Health Organisation, Trans. R. Trop. Med. Hyg., 80, 1-50 (1986).

3) Watkins W. M., Sixsmith D. G., Spencer H. G., Boriga D. A., Karjuki D. M., Kipingor T., Koech D. K., Lancet, 1984-i, 357-359.
4) Neftel K. A., Woodtly W., Schmid M., Br. Med. J., 292, 721-723 (1986).

5) Lind D. E., Leir J. A., Vincent P. C., Br. Med. J., 1, $458-460$ (1973).

6) Maggs J. L., Tingle M. D., Kitteringham N. R., Parks B. K., Biochem. Pharmacol., 37, 303-311 (1988).

7) Christie G., Brechenridge A. M., Park B. K., Biochem. Pharmacol., 38, 1451-1458 (1989).

8) Harrison A. C., Kitteringham N. R., Clarke J. B., Park B. K., Biochem. Pharmacol., 43, 1421-1430 (1992).

9) O’Neill P. M., Harrison A. C., Storr R. C., Hawley S. R., Ward S. A., Park B. K., J. Med. Chem., 37, 1362-1370 (1994).

10) Aziz S. A., Knowles C. O., Nature (London), 242, 417-418 (1973).

11) Beeman R. W., Matsumura F., Nature (London), 242, 273-274 (1973).

12) Meyers A. I., Elworthy T. R., J. Org. Chem., 57, 4732-4740 (1992).

13) Delarue S., Sergheraert C., Tetrahedron Lett., 40, 5847-5890 (1999).

14) Su T. S., Chou T. C., Kim J. Y., Huang J. T., Ciszewska G., Rens W. Y., Otter G. M., Sirotnak F. M., Watanabe K. A., J. Med. Chem., 38, 3226-3235 (1995).

15) Abdel Magid A. F., Carson K. G., Harris B. D., Maryanoff C. A., Shah R. D., J. Org. Chem., 61, 3849-3862 (1996).

16) Ridley R. G., J. Pharm. Pharmacol., 49, 43-48 (1997).

17) Trager W., Jensen J. B., Science, 193, 673-677 (1976).

18) Desjardins R. E., Canfield C. J., Haynes J. D., Chulay J. D., Antimicrob. Agents Chemother., 16, 710-718 (1979).

19) Carmichael J., DeGraff W. G., Gazdar A. F., Minna I. D., Mitchell J. B., Cancer Res., 47, 936-942 (1987). 